\title{
G. B. MORGAGNI AMONG HUMAN PATHOLOGY, FORENSIC MEDICINE AND MUMMIOLOGY. THE BEATIFICATION OF GREGORIO BARBARIGO OF PADUA
}

\author{
G. B. MORGAGNI I LJUDSKA PATOLOGIJA, \\ FORENZIČNA MEDICINA I ZNANOST O \\ MUMIJAMA. BEATIFIKACIJA GRGURA \\ (GREGORIO) BARBARIGE IZ PADOVE
}

\author{
Silvia Marinozzi", Marco Cilione**, Valentina Gazzaniga***
}

\begin{abstract}
Summary
The article is the first step of a research project aimed at investigating new perspectives and aspects of Morgagni's role and work. His activities as a medical examiner and forensic doctor are yet to be truly discovered. Manuscripts, written by Morgagni when he was a forensic expert for the Health Magistrate of Venice, currently preserved at the City Library in Forli (Italy), shed light on a new aspect of his cultural background. As a forensic doctor, he also helped push an increase in "social medicine" in Italy, when physicians began to collaborate with the administrative and political institutions in order to plan environmental and urban regulations to control air quality. While reading his reports, his contribution to the primordial medical Hygiene and Public Health emerges. Among his reports, the authors focused
\end{abstract}

\footnotetext{
Department Molecular Medicine / Unit of History of Medicine and Bioethics, Sapienza University of Rome, Rome, Italy.

** Unit of History of Medicine and Bioethics, Sapienza University of Rome, Rome, Italy.

*** Department of Medico-Surgical Sciences and Biotechnologies / Unit of History of Medicine and Bioethics, Sapienza University of Rome, Rome, Italy.

Correspondence Address: Marco Cilione, Unit of History of Medicine and Bioethics, Sapienza University of Rome, Viale dell’Università 34/a, 00185 Rome, Italy. ORCID ID: https://orcid.org/0000-0002-6960-369X.E-mail: mrccilione@gmail.com.
} 
on the one concerning the Beatification of Gregorio Barbarigo, which clearly highlights his pathological approach, as well as his knowledge and application of embalming systems and mummiology. Moreover, this report could be considered as an issue in the history of paleopathology.

Keywords: G.B. Morgagni, paleopathology, forensic medicine, corpse and beatification, Saint Gregorio Barbarigo

\section{INTRODUCTION}

\section{Morgagni AND FORENSIC MEDICINE}

The work of G.B. Morgagni in anatomical pathology is certainly well known $\mathrm{n}^{1,2,3}$. As many studies have shown, this monumental work represents the birth of pathological anatomy. In the introduction, the reader can see how Morgagni was well aware of the fact that he was writing something truly innovative, where both his personal anatomical observations and those of his predecessors are systematically organised in order to reconstruct the 'clinical histories' of patients who had died. Morgagni sees his work as the chain that links the authoritative colleagues who had preceded him - placing specific focus on $\mathrm{T}$. Bonnet, the author of a treatise reporting a collection of case studies that includes autopsies ${ }^{4}$ - to future generations of pathologists. Morgagni invited them to continue his work and even integrate and correct it through new observations and new autoptic medical experiences.

However, secondary literature has unfortunately not focused on his intensive work on the comparative analysis of the corpses, with reference to the different processes of mummification, or his actual knowledge of taphonomy. According to Morgagni, these aspects are fundamental in order to identify the causes of the death and also define the different degrees of the preservation of the corpse, allowing the physician to correlate the person's death to the severity of the disease. This point clearly emerges when reading the De sedibus et causis morborum per anatomen indagatis. Furthermore, his approach also allowed him to ascertain the type, techniques, and effectiveness

1 Morgagni, Giovan Battista (1761). De sedibus et causis morborum per anatomen indagatis, Venezia; ex Typographia Remondiniana.

2 Zampieri, Fabio, Zanatta, Antonio, Thiene, Gaetano (2015), An etymological "autopsy" of Morgagni's title: De sedibus et causis morborum per anatomen indagatis (1761), Human Pathology, 45 (1), 12-16.

3 Premuda, Loris (1983). "Autopsia" di G.B. Morgagni (1682-1771): il maestro sotto l'obiettivo degli epigoni padovani. Miscellanea di studi in onore di Vittore Branca, IV Tra Illuminismo e Romanticismo, Firenze, 1-12.

4 Bonnet, Theophile (1679). Sepulchretum, seu Anatomia practica ex cadaveribus morbo denatis, Geneve; L. Chouër. 
of embalming performed to mummify the corpses of nobles, cardinals, Popes, bishops, princes, and others. Moreover, he studied the different systems of inhumation and environmental factors, along with the state of preservation and conditions of the corpses. From this point of view, his work might certainly be considered as the initial foundation of a method based on paleopathology, which he often used during his activity as a medical expert for the Venetian Health Magistrate. Within this same context, G.B. Morgagni also provides interesting and lesser-known theoretical contributions. Most scholars see Morgagni as a pathological anatomist, however, his work as a legal, medical expert and ante-litteram hygienist is recognised to a lesser extent by historians. The role and work of Morgagni as a medical examiner and forensic doctor require further study. Importantly, manuscripts by Morgagni, from the time when he was a forensic expert for the Health Magistrate of Venice, have been found in the Hall of records in Forli ${ }^{5}$.

\section{MATERIALS AND METHODS}

\section{MORGAGNi's REPORTS}

In order to gain a more in-depth understanding of his professional role, we need to shed light on his cultural background and his scientific approach. His medical reports and studies tell us a great deal about the place he has earned in the history of medicine, while also highlighting a new aspect of his work. These manuscripts offer an explanation on the correlation among Morgagni's approach to anatomical pathology, forensic medicine, and clinical and mechanistic methodology.

The authors of this paper have examined and transcribed numerous handwritten works, often personally penned and signed by Morgagni himself, found today in the Library of his birthplace in Forli, Italy (in the region of Romagna).

Some of these works reflect the classical tradition of forensic medicine, such as the expert report concerning a lawsuit to annul the marriage for the impotence of $\operatorname{a~man}^{6}$, or the toxic and poisonous power of mercurial medicaments ${ }^{7}$, even the reports on the potential pathological environmental risk

5 Gazzaniga, Valentina, De Angelis, Elio (2000). Giovan Battista Morgagni. Perizie medico-legali, Roma; Carocci.

6 Morgagni G. B., Super impotentia membri genitalis. Biblioteca comunale di Forlì - Aurelio Saffi, Ms., vol. XXXI, ff. 2r-203r.

7 Morgagni G. B. (1736). Sull'uso dell'argento vivo come farmaco. Biblioteca comunale di Forlì - Aurelio Saffi, Ms., vol. XXXI, ff. 176r-184v. 
factors and the transmission of contagious diseases are more interesting and suggestive, clearly oriented toward the social medicine emerging in the $18^{\text {th }}$ century, which represents the combination of jurisprudence, government policies, medical hygiene, prevention, and occupational medicine, that marks the history of forensic medicine until the $19^{\text {th }}$ century.

As a matter of fact, the majority of his studies and reports focus on the risk of air contamination and the transmission of epidemic diseases. His handwritten works offer clear testimony to his support of Ramazzini's theories regarding a scientific epidemiological method to investigate the origin of the epidemic and contagious diseases ${ }^{8}$.

\section{Results}

\section{Morgagni At the Service of PUblic health}

According to Neo-Hippocratic theories, which explain the origin of epidemics with environmental factors such as the air and water quality, Morgagni adopted a 'mechanistic' methodology to connect environmental causes to the insurgence of epidemics ${ }^{9}$. Ancient miasmatic theories - explaining the origin of epidemics as a spontaneous corruption of air - were now being replaced by the scientific study of possible elements that could contaminate our environment. Therefore, he also provides new solutions for the control of air and water quality, conceived as measures for Public Health according to the neo-Hippocratic theories ${ }^{10}$.

For example, he highlights the risk of eating the meat of infected animals or preserving hides and use them as clothes ${ }^{11}$. Moreover, he discusses the risks associated with working in tanneries ${ }^{12}$, cleaning linen clothes or working in fumaroles ${ }^{13}$. Air pollution can also be rooted in factories, often built

8 Conforti, Maria, Gazzaniga, Valentina, Marinozzi, Silvia (2011), Bernardino Ramazzini tra ippocratismo e sperimentalismo. Per la costruzione teorica di una "medicina sociale", Medicina nei Secoli, 23/2, 465-493.

9 Lonie, Iain M. (1981), Hippocrates the Iatromechanist, Medical History 25, c113-150.

10 Marinozzi, Silvia, Gazzaniga, Valentina (2018), Public Health in G.B. Morgagni. New historical perspectives, Journal of Public Health, 40, 4, e611-e613.

11 Morgagni G. B., Se l'uso delle carni e la conservazione delle pelli di pecore morte di vaiolo sia dannoso alla salute, Biblioteca comunale di Forlì - Aurelio Saff, Ms., vol. XXXI, ff. $166 \mathrm{r}-170 \mathrm{v}$.

12 Morgagni, G. B. (1753). Sulle esalazioni delle concerie delle pelli. Biblioteca comunale di Forlì - Aurelio Saffi, Ms., vol. XXXI, ff. 115r-117 and 241r-243v.

13 Morgagni, G. B. (1766). Se gli effluvi che tramandono i lini durante la macerazione possano contribuire all'inquinamento dell'aria. Biblioteca comunale di Forlì - Aurelio Saffi, Ms., vol. XXXI, ff. 139r-141v. 
inside the city centres, due to industrial processes as well as the substances used for production. He also warns of the pathogenic conditions that arise from exhuming corpses that had not yet reached skeletonization, or from digging in old common burials dating back to major epidemics, due to the putrid exhalations ${ }^{14}$. Morgagni was a forerunner of this Italian debate, developed in the $17^{\text {th }}$ century and later becoming a topic of medicine during the Enlightenment ${ }^{15,16,17}$. At that time, it was clear to physicians as well as politicians that an important role in the safeguarding of health was played by removing possible causes of infection caused by urban burials. From this point of view, as a forensic doctor, he also helped push an increase in "social medicine" in Italy, when physicians began to collaborate with the administrative and political institutions in order to plan environmental and urban regulations to control air quality. Following the ancient concept of "miasma", $18^{\text {th }}$-century physicians went further by identifying the putrefied organic matter as the possible origin of dangerous epidemic diseases ${ }^{18}$. Morgagni agreed with this theory, and his reports clearly show his contribution to the primordial medical Hygiene and Public Health.

His work reflects the constant dialogue between jurisprudence and medicine in the $18^{\text {th }}$ century, yet also paired with the social medicine ideals of the Enlightenment. Morgagni's contribution to the construction of an Italian debate on the risk of epidemics, the control of the quality of the air, the research of the origins and the prevention of the contagious diseases (i. e. the analysis of the toxicity of substance largely used in therapy or everyday life), is currently a subject of our ongoing researches on his role in the Public Health, in the medical Hygiene and the Social Medicine.

However, he also highlights the accomplishment of the scientific method, which in 1712 with the Nova institutionum medicarum idea, stated the fundamental importance of a type of new medicine, in which true Knowledge must contain a doctrine. However, this doctrinaire knowledge must be based on the observation of facts, phenomenologically concrete cases, and approaches

14 Morgagni, G. B. (1731). Sulle cautele da prendersi per aprire il sepolcro D'Este. Biblioteca comunale di Forlì - Aurelio Saffi, Ms., vol. XXXI, ff. 118r-125v.

15 Pasini, Piero (2012), Il cimitero moderno: un profilo storico per l'Italia, Ricerche e progetti per il territorio, la città e l'architettura, 4, 191-202.

16 Piattoli, Scipione (1774). Saggio intorno al luogo del seppellire, Modena; F. Sansoni.

17 Rastrelli, Modesto (1784). Storia delle sepolture antiche e moderne ed osservazioni sui nuovi Campi Santi, Firenze; s. e.

18 Ramazzini, Bernardino (1700). De morbis artificum diatriba, Modena; Capponi. 
that go beyond metaphysical speculations ${ }^{19}$, as Thomas Sydenham had highlighted in the introduction of his Constitutiones Epidemicae ${ }^{20}$, manifesto of Neo-Hippocratic medicine, between the affirmation of a scientific epidemiological and diagnostic methodology and the value of "Clinical" medicine as the true art and purpose of medicine. ${ }^{21,22}$

Morgagni uses new knowledge on the structure and function of organs following the "mechanistic" model in order to mechanically explain the parallel between anatomical lesions and clinical phenomena ${ }^{23}$. The correlation among the pathological symptoms, the patient's clinical history, and post-mortem anatomical lesions represents the construction of an epistemological basis of clinical medicine. In short, the program of reformed NeoHippocratic would follow. Morgagni's mentor, Bernardino Ramazzini, was perhaps the epitome of this movement, where anatomical knowledge serves to provide new knowledge of the causes of diseases and the definition of a rational and scientific diagnostic method ${ }^{24}$. This approach can also be traced back to his work as a medical examiner, engaged in different areas of study, from the healthiness of food to air pollution due to miasmatic fumes produced by the putrefaction of organic matter, as well as the study of reasons for Beatification.

\section{Case study: Barbarigo's exhumation}

One of the most interesting studies is that of the beatification of Gregorio Barbarigo (I625-I697), ${ }^{25,26}$ which included both the witnesses to his healing

19 Premuda, Loris, Morgagni Giovan Battista (1982). Nova institutionum medicarum idea. Ristampa dell'edizione padovana del 1712 nel terzo centenario della nascita di G. B. Morgagni (1682-1982), Padova; Tipografia Editrice La Garangola.

20 Sydenham, Thomas (1676). Observationes medicae morborum acutorum historiam et curationem, Londini; G. Kettilby, Praefatio.

21 Sydenham, Thomas (1725). Opera omnia medica, Patavii; typis Seminarii, apud Joannem Manfre.

22 Ongaro, Giuseppe (2008), La distinzione tra sintomi e segni agli inizi della moderna medicina clinica, in: Ongaro, Giuseppe, Storie di medici e di medicina, Padova; Il Poligrafico, 235-245.

23 Zampieri, Fabio (2016). Il metodo anatomo-clinico fra meccanicismo ed empirismo. Marcello Malpighi, Antonio Maria Valsalva, Giovanni Battista Morgagni, Roma; L'Erma di Bretschneider.

24 D'Alessandro, Antonietta (2005). Psiche-Soma: Ippocrate nella letteratura medica del Settecento, Bari; Progedit.

25 Gios Pierantonio (1996). L'itinerario biografico di Gregorio Barbarigo dal contesto familiare all'episcopato. Lettere ai familiari (1655-1657), Padova; Istituto di Storia Ecclesiastica.

26 Giovannucci, Pierluigi (2001). Il processo di canonizzazione del card. Gregorio Barbarigo, Roma; Herder Editrice e Libreria. (Italia Sacra. Studi e documenti di storia ecclesiastica, 66). 
miracles and the incorruptibility of his embalmed body ${ }^{27}$. This document is a useful example of the complete anatomical and pathological approach used by Morgagni since the beginning of his work, also highlighting his expertise as a paleo-pathologist.

The cause for this Beatification began only two years after Barbarigo's death, by collecting witnesses to the holiness of his life, his work and the miracles he was thought to have carried out. In 1723 , under the mandate of Pope Innocent XIII ${ }^{28}$, the Congregation of $\mathrm{Rites}^{29}$ took up the investigation to canonize Barbarigo. In I725, G.B. Morgagni (I682-I77I), as a forensic expert, took part into the exhumation of Barbarigo's body to check if it was still intact, and testify the miracle. In the Catholic religion, the Beatification of a religious person could be considered as the first step for his or her Sanctification. A special commission, the "Congregazione dei Riti" [Congregation of Rites], consisting of Cardinals, Magistrates, Judges and representatives of the Church institutions, institutes a hearing to ascertain if someone is worthy of beatification and/or sanctification. By gathering information on their lives, work of mercy, charity, and miracles that the person performed, this religious tribunal probes witnesses of miraculous doing and feats of the candidates, as well as any exceptional and uncommon event that occurred during and after their lives. The tribunal also analyses any exceptional data regarding the corpse, i.e. incorruptibility, or good preservation, the lack of cadaveric smell, along with the fragrance of a flower exhaling from it.

During the reburial of the remains in a worthier grave inside the Cathedral of Padua in 1727 , Morgagni re-examined the body together with Antonio Vallisneri (1661-1730) and two surgeons, Agostino Danieli and Antonio Maseri, who had embalmed the cardinal's body. For this second exhumation, Vallisneri is also a formal witness, testifying that the body was intact in order not to displease the Congregation of Rites. However, in the letters addressed to Ludovico Antonio Muratori $(\mathrm{I} 672-1750)$ he reported that the body was still well preserved, although there were some signs of decomposition. This was the reason why he stated that it was not a miracle, but

27 Ditchfield, Simon (1995). Liturgy, Sanctity and History in Tridentine Italy: Pietro Maria Campi and the Preservation of the Particular, Cambridge; Cambridge University Press.

28 Dalla Torre, Giuseppe (1991), Santità ed economia processuale. L'esperienza giuridica da Urbano VIII a Benedetto XIV, Archivio Giuridico "Filippo Serafini", 211/1.

29 Gotor, Miguel (2002). I beati del papa. Santità Inquisizione e obbedienza in età moderna, Firenze; Olschki. 
rather something "miraculous" 30 . The ambiguity of his position can be found in a manuscript in which he described the details of his observations ${ }^{31}$. In the 1725 examination, Morgagni also provided a detailed description of the funeral ark, the body and the entrails contained in the leaden box, placed under Barbarigo's head. This box contained Barbarigo's heart, along with the large arteries and other organs. He stated that when the sarcophagus was opened, it did not smell, neither noxious nor scented, which is very important for a cause of beatification. The "Osmogenesia" [Odour of Sanctity], meaning the supernaturally pleasant odour exhaling from the corpse, especially by stigmata or wounds of a person, is even today a constant leitmotiv in the history of the Church. This is also the reason why the smell of flowers is an indication of sanctity itself ${ }^{32}$. This "odour of sanctity" was regarded as a sign that one's holiness had been recognised by the heavens, and as the first post mortem miracle it catalysed a quest for relics cut from the perfumed cadaver ${ }^{33}$. Since Antiquity, as in Greece and Rome, a pleasant and flower odour was considered a divine $\operatorname{sign}^{34,35}$.

Similarly, and at the same time, the olfactory perception has always been one of the most important and essential semeion (sign) to identify diseases and pathological process since Antiquity.

The concept of "miasma" is also strictly connected to the death, phenomenologically represented by the putrefaction of the corpses, and the consequent cadaveric odour exhaling from it as symbol of physical and moral corruption.

Furthermore, from a medical and legal point of view, the identification of the clear cause of air corruption, and therefore of miasmas in putrefied organic matter, also strengthens the importance of the absence or lack of a cadaveric odour or that of a nice fragrance, mostly of flowers, exhaling from the body, in causes for beatification or sanctification.

30 Bouly, Bradford A. (2017). Pious Postmortems: Anatomy, Sanctity, and the Catholic Church in Early Modern Europe. Philadelphia; Pennsylvenia University Press, 82, 183.

31 Vallisneri, Antonio (1725). Biblioteca Universitaria di Pavia, Ms 113, fasc. XII. B.P. 3.

32 Classen, Constance (1998). The Color of Angels: Cosmology, Gender, and the Aesthetic Imagination, London/New York; Routledge.

33 Di Graziano, Frank (2004). Wounds of Love: The Mystical Marriage of Saint Rose of Lima, Oxford; Oxford University Press, 80-83.

34 Harvey, Susan Ashbrooyk (2001), On Holy Stench: When the Odor of Sanctity Sickens, Studia patristica, 35, 90-101.

35 Harvey, Susan Ashbrook, Mullett, Margaret (2017). Knowing Bodies, Passionate Souls. Sense Perceptions in Byzantium, Washington; Dumbarton Oaks Research Library and Collection. 
The tradition of embalming or performing the "unction" of the body with scented oil, balsams and powders, prepared with flowers and perfumed substances, allowed for the infusion of an abiding and permanent sweet odour to the corpses. This tradition is truly important for Saints, even if the inspections performed by a medical and religious expert must consider if the body has been embalmed, and distinguish the fragrances exhaling from embalming substance or rather the odour of the corpse ${ }^{36}$. As a matter of fact, he analysed the list of the herbs used to embalm the corpse of Barbarigo.

The fact that Morgagni denied the existence of this odour is undoubtedly remarkable in the study of his reports, which go on for years in order to find out reliable evidence for Barbarigo's beatification. However, even the lack of the odour from putrefaction leads to a praeternatural (i.e. supernatural phenomenon) sign alone, and sufficient to make the fact extraordinary, however, Morgagni defines this as not miraculous, perhaps considering that the funeral embalming led to the putrefaction of the corpse and, consequently, the cadaveric odour.

Once again, Morgagni reported the presence of moisture both on the garments and the exposed parts of the body, which appeared darker compared to those covered by the garments, possibly due to either the penetration or the formation of condensation for environmental reasons ${ }^{37}$. In 1727 , he noted the dark complexion on the skin of the face and the uncovered part of the body, while those under the garments preserved their natural colour. By rubbing the blackened areas of the body, a sticky patina remained adherent to the finger, and the pink colour of the skin could be seen. Therefore, regarding the black slurry dripping from the leaden box, he also found the formation of a blackish layer on the entire surface of the body, both on the exposed parts and the garments. He noted that all the parts were preserved and the fact that the eyes were still soft, (there would be no fluids neither from the nose, nor the mouth, no signs of necrosis of the blood vessels) was considered to be admirable even though Maseri had practised only partial embalming by eviscerating the thoraco-abdominal cavity without the extraction of the brain and fleshes, which the surgeon called "scarification", i.e. the removal of flesh and muscles from the legs, the arms and sometimes from the back and the abdominal zone.

36 Fulcheri, Ezio (2013), Canonic Recognitions and Scientific Investigations on Mummies of Saints, Medicina nei Secoli, 25, 139-165.

37 Morgagni, G. B. (1725). Sull'esumazione della salma del beato Cardinale Gregorio Barbarigo, Biblioteca comunale di Forlì - Aurelio Saff, Ms., vol. XXXI, ff. 82r-92r. 
By reading the statements given by witnesses to the Congregation of Rites during the Beatification hearing, we found a short communication of the observation of G.B. Morgagni on the partial embalming ${ }^{38}$, while the chronicler Ricchini wrote that the surgeon performed the usual embalming reserved to all the Cardinals ${ }^{39}$. This was generally carried out with a total evisceration of every cavity of the cadaver, meaning the extraction of all the viscera, sometimes even by the scarification ${ }^{40}$. Morgagni reported that the corpse and the viscera, protected in the box, were well preserved. However, the garments were damaged, unrecognizable even compared to the examination of 1725 , perhaps due to contact with the air during the first exhumation. He considered the fact that the Barbarigo's body did not show new signs of decomposition and that it was in the same conditions that he had tested in 1725, a miraculous event, as the pathological process had not corrupted the flesh. He also observed that the garments had not undergone any process for their preservation. That said, the preservation of the corpse might also be ascribed to an unnatural cause, since the body had been sprinkled and washed with the spirit of wine and aromatic substances, as in every traditional embalming system. Therefore, Morgagni refrained from giving a final judgement on whether the integrity of Barbarigo's body was a miracle or not ${ }^{41}$.

The first investigation ended in 1728 , although between 1743 and 1748 the Bishop of Padua, Carlo Rezzonico, reopened the trial and hearings for the canonization of the Cardinal. The procedure that would eventually lead to his beatification began in 1775. Barbarigo's beatification took place on July $\mathrm{I}^{\text {th }}, \mathrm{I} \mathrm{I}^{42}$. In September $176 \mathrm{I}$, the Judiciary of Health in Venice called Morgagni back to exhume Barbarigo's corpse in order to witness miraculous integrity. In his evaluation, he reported that the corpse was in the same condition of preservation that he had already observed in 1725 and 1727 . However, as he had stated in his 1727 report, there was still the presence of dark slurry at the bottom of the coffin, which Morgagni decided to clean. With respect for the corpse, he undressed the mummy: the chest and the

38 Congregazione de' Riti (1761). Ragguaglio della vita, virtù, e miracoli del B. Gregorio Barbarigo, Roma; Generoso Salomoni, 172.

39 Ricchini, Tommaso Agostino (1761). Vita del beato Gregorio Barbarigo cardinale della S. Romana Chiesa vescovo di Padova, Padova; Presso Generoso Salomoni, 159.

40 Marinozzi, S. (2013), Corpi, mummie e testi per una storia dell'imbalsamazione funebre in Italia, Medicina nei Secoli, 25/1, 167-204.

41 Morgagni, G. B. (1727). Sull'esumazione della salma del beato Cardinale Gregorio Barbarigo, Biblioteca comunale di Forlì - Aurelio Saffi, Ms., vol. XXXI, ff. 64r-66v; 74v.

42 Menniti, Ippolito A. (2003), Il processo di canonizzazione di Gregorio Barbarigo. Riflessioni su un volume recente, Rivista di storia della Chiesa in Italia, 57, 185-196. 
stomach were compressed, reclined, and they did not retain the right shape of a body, which had been perfectly preserved. Morgagni had to test that the pathological process had not destroyed and corrupted any part of the body.

Consequently, he decided to examine the corpse in order to testify the real conditions and the state of preservation of the corpse. He took notes on his observations and the data obtained by examining the corpse, as well as all the operations he performed on the mummy.

He undressed the corpse due to the fact that the garments had absorbed moisture from the water that had penetrated into the sarcophagus. He then reopened the chest, taking out the stitches that the embalmer had used to close the incision that had been made to eviscerate the body. The chest was removed to be used as a relic for the cities of Bergamo and Padua, and the third left rib was removed for Clement XIII. From the box placed under the corpse's head, they took out the liver as well, which they delivered as a relic to Pius VII in 1800 .

After removing the sternum, Morgagni was able to replace the embalming stuffing that was no longer adequate. By consulting the manuscript prepared by the pharmacist Carlo Scarella, which he had already transcribed in the 1727 report to list the herbs with which he had filled the eviscerated cavities, Morgagni managed to substitute the rotten herbs with the fresh ones of the same type. When the restoration was complete, instead of using the burial garments, which were soaked with water, "si stese un panno di lino, ed a questo furono sopraposte le due parti anteriori d'un piviale..." (omissis)" - "a linen cloth was laid and the front pieces of a cope were placed on it ..." ${ }^{43}$.

In his report, he also wrote that the fact that the body, in his opinion, had remained as it was in 1725 (though the right hand was damaged due to the fall of the top leaden slab during the transfer of the body), while both the garments and the entrails, in contact with the air in the previous exhumation, were deteriorated, led him to define the phenomenon as something admirable, providing scientific elements to justify Barbarigo's beatification.

Following traditional medical doctrines, Barbarigo's illness should have caused an abnormal production of putrefactive humours that would have corrupted the viscera and the corpse.

43 Morgagni, G. B. (1761). Sull'esumazione della salma del beato Cardinale Gregorio Barbarigo, Biblioteca comunale di Forlì - Aurelio Saffi, Ms., vol. XXXI, ff. 63r-63v. 
We know that on the night of June $13^{\text {th }}, 1697$, after celebrating mass for St. Antony of Padua, Barbarigo caught a fever. During the following days, he was unable to eat and had abdominal pain and shortness of breath. When these symptoms grew worse, physicians declared the illness had already invaded the viscera ${ }^{44}$.

According to the medical tradition, by the descriptions of the pathological symptoms and process of the disease of Barbarigo in the last days of his life, we might suppose that the physicians ascribed the cause of his death to a pletora, meaning an abnormal quantity of corrupted fluids, especially of phlegma or/and atra bile that induced a corruption of the viscera. In ancient medical tradition, the majority of mortal pathologies were caused by the production of cold humours, phlegma and black-bile, altering and changing the natural physiological process, affecting and reducing the innate heat, and inducing an imbalance of the person's vital factors and natural physiology.

\section{Discussion}

MORGAGNi's INFLUENCE ON NOSOLOGY OF DISEASES: NEW PERSPECTIVES OF RESEARCH

In the $18^{\text {th }}$ century, doctors developed a new nosology of diseases, classifying them according to symptoms, the systems affected and the causes. It is precisely the search for a methodical criterion in tracing causes and aetiology, in a close cause-effect relationship, which allows for a new reading of ancient medical texts in the light of new anatomical-physiological discoveries in a "mechanical" perspective in the definition of the causes of illness. The demonstration of blood circulation, with the publication of W. Harvey's work ${ }^{45}$, opens new paths and perspectives in pathological definitions ${ }^{46,47}$. Blood density or rarefaction, its fast or slow motion, as well as the mixture of fatty, bilious and putrid humours in the blood mass, all become crucial elements in pathological interpretations. These factors are important along with chemical and mechanistic terms, but also in light of new "vitalistic" theories, which aim to overcome a hydro-mechanical or only chemical

44 Ricchini, T. A. (1761).

45 Harvey, William (1628). Exercitatio anatomica de motu cordis et sanguinis in animalibus, Francoforte; Guilielmi Fitzeri.

46 Stevenson, Lloyd G (1966), "New Diseases" in the Seventeenth Century, Bulletin of the History of Medicine, 39, 1, 1-21.

47 Porter, Roy (1985), Dizionario Bibliografico della Storia della Medicina e delle Scienze Naturali (Liber Amicorum), Tomo II, Milano; Franco Maria Ricci. 
vision, in a holistic vision of the body on the one hand, and a reduction to purely organic and essential factors of the causes of disease and death on the other.

Although "Vitalism" saw growth above all in the countries of the Alps, the idea of a force inherent in matter itself, of an organism's own vital principles - thanks also to corpuscular theories - allowed for the conjugation of the iatro-chemical model within a mechanistic conception of the body. In this model, fibres or solid parts are as essential as the humours and the blood in the development of a new anatomical-physiology and anatomical-pathology. Morgagni explicitly refers to authors who preceded him, such as Marcello Malpighi, and peers, such as Giorgio Baglivi ${ }^{48}$ and Giovanni Maria Lancisi, with whom he worked together, underlining the alteration of organs or fibres in autopsies.

Based on a new reading of Hippocrates ${ }^{49}$, G.M. Lancisi stated that life was a balance of three functions and three essential organs: the heart, which coordinates the circulation; the brain, which processes the vital spirit into animal spirits, infuses it to all parts of the body through the nerve fluid; and lastly, the lungs, which purify and vivify the blood with air ${ }^{50}$.

There was also the support of the concept based on a close connection between the digestive system and the brain, among the filtering, expelled, digestive and transformative roles of what is necessary for the organism, as well as the digestive system and the functions of the other vital organs. For many authors, the intestine is the primary site of peristaltic motion, that is, the wave motion given by the involuntary nervous contraction of the muscle structures (present in the tubular organs), which is its maximum representation, maximum irritability, in analogy to the brain as the primary site of sensitivity. In short, the ancient concepts of fluxion and sympathy are brought back, reinterpreted under new medical doctrines. Due to the fact that the body expresses the physiological and pathological trend of these vital forces, it is possible for physicians to understand internal dynamics and the origin of diseases based on organic manifestations such as phenomena of vital motions, and consequently choose adequate therapy. The Hippocratic concept

48 Tonetti, Luca (2017), Corpus fasciculus fibrarum: Teoria della fibra e pratica medica nel De praxi medica di Giorgio Baglivi, Physis, 51, 379-392.

49 Manuli, Paola, Vegetti, Mario (2009). Cuore, sangue e cervello: biologia e antropologia nel pensiero antico, Pistoia; Petite Plaisance.

50 Donato, Maria Pia (2009), The Mechanical Medicine of a Pious Man of Science: Lancisi's De subitaneis mortibus (1707), in: Donato M. P., Kraye J. eds, Conflicting Duties. Science, Medicine and Religion in Rome, 1550-1750, London; Warburg Institut, 339-374. 
of "sympathy", which leads back to a holistic conception of the body, agrees with the new vision of life as an expression of the only vital principle, a set of inherent forces and agents - that in a state of natural balance, meaning good health - are coordinated with each other in intensity, functions, and mutual interactions. . $^{51,52,53}$

Based on this perspective, the "pletoric" process (i.e. the overabundance of cold humours), perhaps originating in the stomach, also involved the brain. Consequently, through the nerves, the hearth was also corrupted, putrefying the blood and every part of the body, leading to a septic process.

Italian physicians, such as Morgagni, applied the vitalistic, corpusculistic, chemical, and mechanical theories to define a new rational and scientific method for a mechanical interpretation of the physiology and the pathology ${ }^{54}$.

The fact that Morgagni, in previous reports and studies, used the same words of Vallisneri (that the preservation of the corpse was "something admirable"), and not clearly defining it as a real miracle and deciding to restore the mummy, which he could not ascertain the total integrity, leads us to believe that the restoration was a sort of ploy in order to allow him to agree with the previously declared beatification.

At the will of Pope Clement XIII, the Cardinal was beatified. Two centuries later, in 1960, he was also sanctified by Pope John XXIII.

In 1997, two pathologists, Wien Marin and Cappelletti, carried out the last exhumation. A wax mask covered a blackened face, perhaps due to taphonomic effects. The orbital sockets had been emptied, and the hands had been amputated and replaced with plaster implants. Both the legs and the thorax and abdomen had been bandaged with numerous layers of fabric as if there had been a second restoration. A description of other exhumations does not emerge from the documents analysed by the pathologists, except

51 Monti, Maria Teresa (1990). Congettura ed esperienza nella fisiologia di Haller. La riforma dell'anatomia animata e il sistema della generazione, (Biblioteca di Nuncius), Firenze; Leo S. Olschki, 45-113.

52 Reill, Peter H. (2005). Vitalizing Nature in the Enlightenment. Berkeley, Los Angeles/ London; University of California Press, 33-158.

53 Cimino, Guido, Duchesneau, François (1997), Vitalism from Haller to the cell theory, Proceedings of the Zaragoza Symposium. XIXth International Congress of History of Science (22-29 August 1993), Biblioteca di Physis, 25, Firenze; Olschki.

54 Zampieri, Fabio (2016). Il metodo anatomo-clinico fra meccanicismo ed empirismo. Marcello Malpighi, Antonio Maria Valsalva, Giovanni Battista Morgagni, Roma; L'Erma di Bretschneider. 
for that of 1817 , during which the ring finger of the right hand had been amputated for the cardinal Ercolani, albeit without any detailed description of the conditions of the body ${ }^{55}$. These reports still remain a mystery today. When, why and who is responsible for these restorations after Morgagni? His re-embalming of the corpse, ensuring its integrity, was certainly crucial for the sanctification of Barbarigo.

New research might shed light on these unsolved questions, opening new theses to be explored. Further research could also offer an innovative look at how we see Morgagni's work, perhaps better demonstrating his importance for the development of this scientific discipline.

Although a new exhumation of the corpse offers more information and data, also using isotopic and molecular analysis and imaging exams, we now certainly have important information on the significance of forensic medicine and the emerging anatomical and pathological medicine in the $18^{\text {th }}$ century as well as their clear correlations. Moreover, the ability of G. B. Morgagni to investigate these mummies clearly emerges by an approach that we can define as a primordial methodology for the investigations in paleopathology. His work comes a century before the studies performed by pathologists on human remains in the second part of the $19^{\text {th }}$ century, which traditional historical and medical literature still considers as the first step for the development of paleopathology.

\section{Disclosure}

The authors declare that they have no known competing financial interests or personal relationships that could have influenced the work reported in this paper.

The authors ensure that they have written these original works in their entirety.

The authors ensure that no human beings have been involved for the research.

55 Terribile Wiel Marin, Vito, Cappelletti, Elsa M. (1997), L'imbalsamazione del corpo di San Gregorio Barbarigo e la sua ricognizione nel 1997, Atti e memorie della Accademia italiana di storia della farmacia, 14 (3), 224-234. 


\section{REFERENCES}

1. Bonnet, Theophile (1679). Sepulchretum, seu Anatomia practica ex cadaveribus morbo denatis, Geneve; L. Chouër.

2. Bouly, Bradford A. (2017). Pious Postmortems: Anatomy, Sanctity, and the Catholic Church in Early Modern Europe. Philadelphia; Pennsylvenia University Press, 82, 183.

3. Cimino, Guido, Duchesneau, François (1997), Vitalism from Haller to the cell theory, Proceedings of the Zaragoza Symposium. XIXth International Congress of History of Science (22-29 August 1993), Biblioteca di Physis, 25, Firenze; Olschki.

4. Classen, Constance (1998). The Color of Angels: Cosmology, Gender, and the Aesthetic Imagination, London/New York; Routledge.

5. Conforti, Maria, Gazzaniga, Valentina, Marinozzi, Silvia (2011), Bernardino Ramazzini tra ippocratismo e sperimentalismo. Per la costruzione teorica di una "medicina sociale", Medicina nei Secoli 23/2, 465-493.

6. Congregazione de' Riti (1761). Ragguaglio della vita, virtù, e miracoli del B. Gregorio Barbarigo, Roma; Generoso Salomoni.

7. D'Alessandro, Antonietta (2005). Psiche-Soma: Ippocrate nella letteratura medica del Settecento, Bari; Progedit.

8. Dalla Torre, Giuseppe (1991), Santità ed economia processuale. L'esperienza giuridica da Urbano VIII a Benedetto XIV, Archivio Giuridico "Filippo Serafini", 211/1.

9. Di Graziano, Frank (2004). Wounds of Love: The Mystical Marriage of Saint Rose of Lima, Oxford; Oxford University Press.

10. Ditchfield, Simon (1995). Liturgy, Sanctity and History in Tridentin Italy: Pietro Maria Campi and the Preservation of the Particular, Cambridge; Cambridge University Press.

11. Donato, Maria Pia (2009), The Mechanical Medicine of a Pious Man of Science: Lancisi's De subitaneis mortibus (1707), in: Donato M.P., KrayeJ. eds, Conflicting Duties. Science, Medicine and Religion in Rome, 1550-1750, London; Warburg Institut, 339-374.

12. Fulcheri, Ezio (2013), Canonic Recognitions and Scientific Investigations on Mummies of Saints, Medicina nei Secoli, 25, 139-165.

13. Gazzaniga, Valentina, De Angelis, Elio (2000). Giovan Battista Morgagni. Perizie medico-legali, Roma; Carocci.

14. Gios Pierantonio (1996). L'itinerario biografico di Gregorio Barbarigo dal contesto familiare all'episcopato. Lettere ai familiari (1655-1657), Padova; Istituto di Storia Ecclesiastica. 
15. Giovannucci, Pierluigi (2001). Il processo di canonizzazione del card. Gregorio Barbarigo, Roma; Herder Editrice e Libreria. (Italia Sacra. Studi e documenti di storia ecclesiastica, 66).

16. Gotor, Miguel (2002). I beati del papa. Santità Inquisizione e obbedienza in età moderna, Firenze; Olschki.

17. Harvey, Susan Ashbrook (2001), On Holy Stench: When the Odor of Sanctity Sickens, Studia patristica, 35, 90-101.

18. Harvey, Susan Ashbrook, Mullett, Margaret (2017). Knowing Bodies, Passionate Souls. Sense Perceptions in Byzantium, Washington; Dumbarton Oaks Research Library and Collection.

19. Harvey, William (1628). Exercitatio anatomica de motu cordis et sanguinis in animalibus, Francoforte; Guilielmi Fitzeri.

20. Lonie, Iain M. (1981), Hippocrates the Iatromechanist, Medical History 25, c113-150.

21. Manuli, Paola, Vegetti, Mario (2009). Cuore, sangue e cervello: biologia e antropologia nel pensiero antico, Pistoia; Petite Plaisance.

22. Marinozzi, Silvia (2013), Corpi, mummie e testi per una storia dell'imbalsamazione funebre in Italia, Medicina nei Secoli, 25/1, 167-204.

23. Marinozzi, Silvia, Gazzaniga, Valentina (2018), Public Health in G.B. Morgagni. New historical perspectives, Journal of Public Health, 40, 4, e611-e613.

24. Menniti, Ippolito A. (2003), Il processo di canonizzazione di Gregorio Barbarigo. Riflessioni su un volume recente, Rivista di storia della Chiesa in Italia, 57, 185-196.

25. Monti, Maria Teresa (1990). Congettura ed esperienza nella fisiologia di Haller. La riforma dell'anatomia animata e il sistema della generazione, (Biblioteca di Nuncius), Firenze; Leo S. Olschki.

26. Morgagni, Giovan Battista (1725). Sull'esumazione della salma del beato Cardinale Gregorio Barbarigo, Biblioteca comunale di Forlì - Aurelio Saffi, Ms., vol. XXXI, ff. 82r-92r.

27. Morgagni, Giovan Battista (1727). Sull'esumazione della salma del beato Cardinale Gregorio Barbarigo, Biblioteca comunale di Forlì - Aurelio Saffi, Ms., vol. XXXI, ff. 64r-66v; 74v.

28. Morgagni, Giovan Battista (1731). Sulle cautele da prendersi per aprire il sepolcro D'Este. Biblioteca comunale di Forlì - Aurelio Saffi, Ms., vol. XXXI, ff. $118 \mathrm{r}-125 \mathrm{v}$.

29. Morgagni Giovan Battista (1736). Sull'uso dell'argento vivo come farmaco. Biblioteca comunale di Forlì - Aurelio Saffi, Ms., vol. XXXI, ff. 176r-184v. 
30. Morgagni, Giovan Battista (1753). Sulle esalazioni delle concerie delle pelli. Biblioteca comunale di Forlì - Aurelio Saff, Ms., vol. XXXI, ff. 115r-117 and $241 \mathrm{r}-243 \mathrm{v}$.

31. Morgagni, Giovan Battista (1761). De sedibus et causis morborum per anatomen indagatis, Venezia; ex Typographia Remondiniana.

32. Morgagni, Giovan Battista (1761). Sull'esumazione della salma del beato Cardinale Gregorio Barbarigo, Biblioteca comunale di Forlì - Aurelio Saffi, Ms., vol. XXXI, ff. 63r-63v.

33. Morgagni, Giovan Battista (1766). Se gli effluvi che tramandono i lini durante la macerazione possano contribuire all'inquinamento dell'aria. Biblioteca comunale di Forlì - Aurelio Saffi, Ms., vol. XXXI, ff. 139r-141v.

34. Morgagni Giovan Battista, Super impotentia membri genitalis. Biblioteca comunale di Forlì - Aurelio Saff, Ms., vol. XXXI, ff. 2r-203r.

35. Morgagni Giovan Battista. Se l'uso delle carni e la conservazione delle pelli di pecore morte di vaiolo sia dannoso alla salute, Biblioteca comunale di Forlì Aurelio Saffi, Ms., vol. XXXI, ff. 166r-170v.

36. Ongaro, Giuseppe (2008), La distinzione tra sintomi e segni agli inizi della moderna medicina clinica, in: Ongaro, Giuseppe, Storie di medici e di medicina, Padova; Il Poligrafico, 235-245.

37. Pasini, Piero (2012), Il cimitero moderno: un profilo storico per l'Italia, Ricerche e progetti per il territorio, la città e l'architettura, 4, 191-202.

38. Piattoli, Scipione (1774). Saggio intorno al luogo del seppellire, Modena; F. Sansoni.

39. Porter, Roy (1985), Dizionario Bibliografico della Storia della Medicina e delle Scienze Naturali (Liber Amicorum), Tomo II, Milano; Franco Maria Ricci.

40. Premuda, Loris, Morgagni Giovan Battista (1982). Nova institutionum medicarum idea. Ristampa dell'edizione padovana del 1712 nel terzo centenario della nascita di G. B. Morgagni (1682-1982), Padova; Tipografia Editrice La Garangola.

41. Premuda, Loris (1983). "Autopsia" di G.B. Morgagni (1682-1771): il maestro sotto l'obiettivo degli epigoni padovani. Miscellanea di studi in onore di Vittore Branca, IV Tra Illuminismo e Romanticismo, Firenze, 1-12.

42. Ramazzini, Bernardino (1700). De morbis artificum diatriba, Modena; Capponi.

43. Rastrelli, Modesto (1784). Storia delle sepolture antiche e moderne ed osservazioni sui nuovi Campi Santi, Firenze; s. e.

44. Reill, Peter H. (2005). Vitalizing Nature in the Enlightenment. Berkeley, Los Angeles/London; University of California Press. 
45. Ricchini, Tommaso Agostino (1761). Vita del beato Gregorio Barbarigo cardinale della S. Romana Chiesa vescovo di Padova, Padova; Presso Generoso Salomoni.

46. Stevenson, Lloyd G. (1966), "New Diseases" in the Seventeenth Century, Bulletin of the History of Medicine, 39, 1, 1-21.

47. Sydenham, Thomas (1676). Observationes medicae morborum acutorum historiam et curationem, Londini; G. Kettilby, Praefatio.

48. Sydenham, Thomas (1725). Opera omnia medica, Patavii; typis Seminarii, apud Joannem Manfre.

49. Terribile Wiel Marin, Vito, Cappelletti, Elsa M. (1997), L'imbalsamazione del corpo di San Gregorio Barbarigo e la sua ricognizione nel 1997, Atti e memorie della Accademia italiana di storia della farmacia 14 (3), 224-234.

50. Tonetti, Luca (2017), Corpus fasciculus fibrarum: Teoria della fibra e pratica medica nel De praxi medica di Giorgio Baglivi, Physis, 51, 379-392.

51. Vallisneri, Antonio (1725). Biblioteca Universitaria di Pavia, Ms 113, fasc. XII. B.P. 3.

52. Zampieri, Fabio (2016). Il metodo anatomo-clinico fra meccanicismo ed empirismo. Marcello Malpighi, Antonio Maria Valsalva, Giovanni Battista Morgagni, Roma; L'Erma di Bretschneider.

53. Zampieri, Fabio, Zanatta, Antonio, Thiene, Gaetano (2015), An etymological "autopsy" of Morgagni's title: De sedibus et causis morborum per anatomen indagatis (1761), Human Pathology, 45 (1), 12-16. 


\section{SAŽETAK}

Ovaj rad je prvi korak istraživačkog projekta kojemu je cilj istražiti nove perspektive i aspekte Morgagnijeve uloge i rada. Njegove aktivnosti kao medicinskog ispitivača $i$ forenzičnog liječnika tek trebaju biti otkrivene. Rukopisi, koje je napisao Morgagni kada je bio forenzički stručnjak Zdravstvenog magistrata u Veneciji, a koji se trenutačno čuvaju u Gradskoj knjižnici u Forliju (Italija), osvjetljavaju novi aspekt njegove kulturne pozadine. Kao forenzički liječnik pomogao je i razvoju socijalne medicine u Italiji, kada su liječnici počeli suradivati s administratiunim i političkim institucijama pri planiranju okolišnih i urbanističkih propisa za kontrolu kvalitete zraka. Čitajući njegova izvješća, uočljiv je njegov doprinos prapočecima medicinske higijene i javnog zdravstva. Autori su se usredotočili na izvješće koje se odnosi na beatifikaciju Grgura Barbarige, a koje ističe njegov pristup u patologiji, kao i njegovo znanje i primjenu balzamičnih sustava $i$ znanosti o mumijama. Štoviše, ovo bi se izvješće moglo smatrati bitnim u povijesti paleopatologije.

Ključne riječi: G. B. Morgagni, paleopatologija, forenzična medicina, tijelo i beatifikacija, sveti Grgur (Gregorio) Barbarigo 